\title{
Topoclimatological case-study of Alpine pastures near the Albula Pass in the eastern Swiss Alps
}

\author{
P. Michna ${ }^{1}$, W. Eugster ${ }^{2}$, R. V. Hiller ${ }^{2}$, M. J. Zeeman ${ }^{3}$, and H. Wanner ${ }^{1}$ \\ ${ }^{1}$ University of Bern, Institute of Geography, Hallerstrasse 12, 3012 Bern, Switzerland \\ ${ }^{2}$ ETH Zürich, Institute of Agricultural Sciences, Universitätsstrasse 2, 8092 Zürich, Switzerland \\ ${ }^{3}$ Karlsruhe Institute of Technology, Institute of Meteorology and Climate Research (IMK-IFU), \\ Kreuzeckbahnstr. 19, 82467 Garmisch-Partenkirchen, Germany \\ Correspondence to: W. Eugster (eugsterw@ethz.ch)
}

Received: 30 January 2013 - Revised: 25 April 2013 - Accepted: 6 June 2013 - Published: 16 December 2013

\begin{abstract}
Alpine grasslands are an important source of fodder for the cattle of Alpine farmers. Only during the short summer season can these pastures be used for grazing. With the anticipated climate change, it is likely that plant production - and thus the fodder basis for the cattle - will be influenced. Investigating the dependence of biomass production on topoclimatic factors will allow us to better understand how anticipated climate change may influence this traditional Alpine farming system. Because small-scale topoclimatological variations of the main meteorological variables: temperature, humidity, precipitation, shortwave incoming radiation and wind speed are not easily derived from available long-term climate stations in mountainous terrain, it was our goal to investigate the topoclimatic variations over the pastures belonging to the Alp Weissenstein research station north of the Albula Pass in the eastern Swiss Alps. We present a basic assessment of current topoclimatic conditions as a site characterization for ongoing ecological climate change studies. To be able to link short-term studies with long-term climate records, we related agrometeorological measurements with those of surrounding long-term sites run by MeteoSwiss, both on valley bottoms (Davos, Samedan), and on mountain tops (Weissfluhjoch, Piz Corvatsch). We found that the Davos climate station north of the study area is most closely correlated with the local climate of Alp Weissenstein, although a much closer site (Samedan) exists on the other side of the Albula Pass. Mountain top stations, however, did not provide a convincing approximation for the climate at Alp Weissenstein. Direct comparisons of near-surface measurements from a set of 11 small weather stations distributed over the domain where cattle and sheep are grazed indicate that nocturnal minimum air temperature and minimum vapor pressure deficit are mostly governed by the altitudinal gradient, whereas daily maxima - including also wind speed - are more strongly depending on vegetation cover and less on the altitude.
\end{abstract}

\section{Introduction}

Alpine grasslands are an important source of fodder for the cattle of Alpine farmers. The traditional Swiss Alpine farming system uses three elevations to raise cattle: in the winter the animals are kept on the lowest elevation in the valleys and the cattle are fed mostly with hay and grains that can be stored in the main farm buildings. This traditional system is described in detail for the Canton of Grisons by Weiss (1941). When the growing season starts, the cattle are driven up to the second level of pastures and meadows, the so-called
Maiensäss altitudinal belt. When the snow has disappeared from the low-alpine areas, the cattle are moved further up to the Alpine pastures where they stay during the short summer (roughly three months from mid-June to mid-September).

At ETH Zürich, this traditional Alpine farming system is represented by three research stations (see Fig. 1): Chamau at $400 \mathrm{~m}$ a.s.l. representing the valley bottom winter location, Früebüel on $1000 \mathrm{~m}$ a.s.l. represents the Maiensäss belt (spring and fall), and Alp Weissenstein on $2000 \mathrm{~m}$ a.s.l. (summer) is the third level (Eugster and Leuenberger, 2007; Zeeman et al., 2010). The yield of alpine grasslands can be 


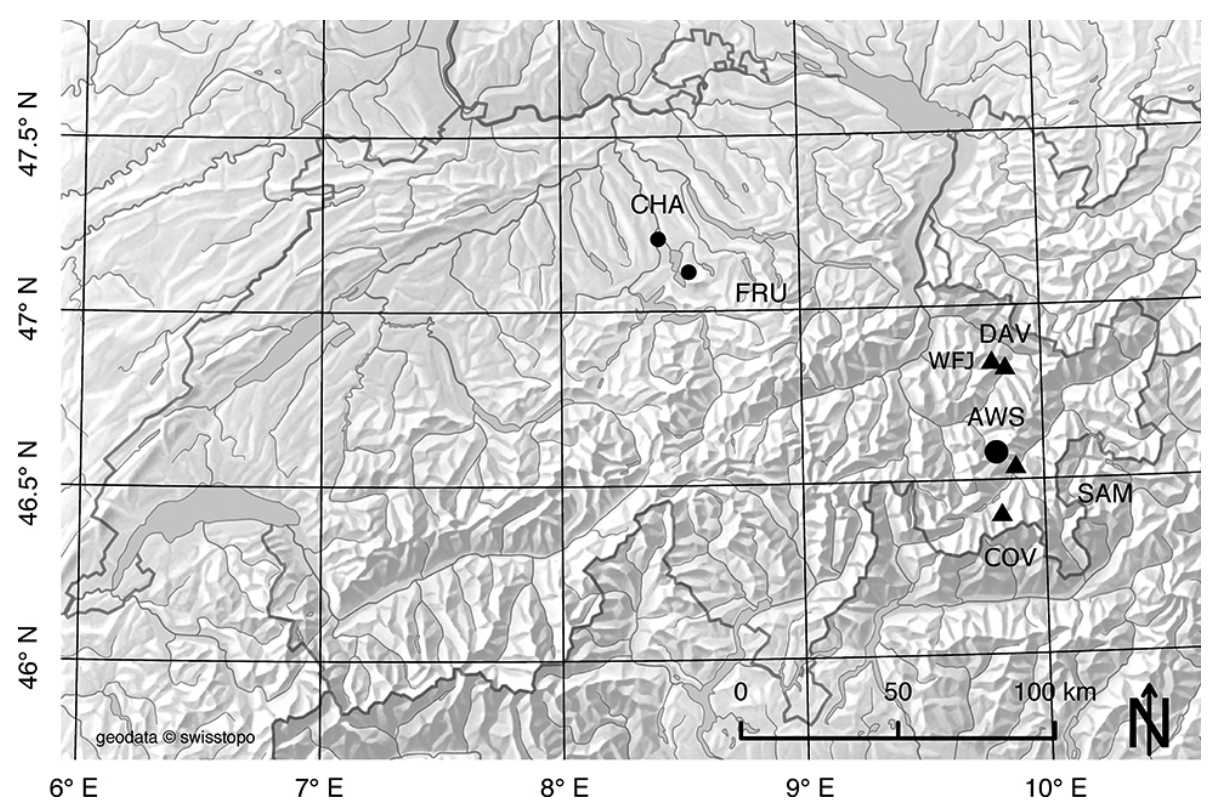

Figure 1. Overview map of Switzerland. The locations of the three agricultural research stations of ETH are indicated with black dots. CHA denotes Chamau, FRU Früebüel, and AWS Alp Weissenstein. The four MeteoSwiss weather stations Davos (DAV), Samedan (SAM), Weissfluhjoch (WFJ) and Corvatsch (COV) are indicated with black triangles.

increased considerably with careful Alp management. However, quantitative estimates have not been made so far to assess how topoclimatological factors influence plant biomass production of Alpine pastures. Therefore, it was our goal to provide a topoclimatological characterization of the pastures belonging to the Alp Weissenstein research station. In an earlier project (Hiller, 2007; Hiller et al., 2008; Zeeman et al., 2010), the net biomass production was measured at a representative site on this location (Fig. 2a). Combining this topoclimatological assessment and the quantification of biomass production will allow us to better understand how Alpine pasture productivity depends on climate and how anticipated climate change may influence the traditional Alpine farming system in the Swiss Alps.

Valley-scale topoclimatological studies are rare (see also Zhenlin et al., 2011). Available studies include the nearby Dischma Valley, located $20 \mathrm{~km}$ NNE of Davos (Urfer, 1981; Urfer-Henneberger, 1970; Urfer-Henneberger and Turner, 1982), the French Alps (Douguedroit, 1984; Carrega, 1995), northern Sweden (Zhenlin et al., 2011), and an isolated hill in northern England (Harrison and Kelly, 1996). An overview of the climatology of the upper Albula Valley, where the Alp Weissenstein research site is located, can be found in Urfer et al. (1979). Their interpretation is that the climate of the Albula Valley corresponds more to the Northern Alpine than the Southern Alpine climate, a finding that is mainly based on conceptual reasoning without actual field data.

In our case study from the ETH research station Alp Weissenstein near the Albula Pass, we characterize the topoclimatic variation of Alpine pastures. The aim is (1) to provide basic insights in small-scale spatial variations in mountain valley climate, and (2) to provide a basis for ongoing ecological climate change research (Hiller et al., 2008; Zeeman et al., 2010; and follow-up studies). We give an overview on the characteristics of the research area and the instrumentation, followed by a description of the climate for the years 2006-2008, in comparison to the nearest MeteoSwiss longterm weather stations, and a comparison of measurements obtained from paired weather stations on differently vegetated and unvegetated surfaces.

\section{Experimental design}

\subsection{Area description}

The Alp Weissenstein is an agricultural research station run by ETH Zürich since 1967 (Eugster and Leuenberger, 2007). It is situated in the eastern Swiss Alps, in the headwater catchment of the Albula Valley, just below the Albula Pass (Fig. 1). South and southwest facing pastures range from $1900 \mathrm{~m}$ to around $2600 \mathrm{~m}$ a.s.l. with surrounding mountain ranges reaching altitudes of up to $3016 \mathrm{~m}$ a.s.l. Most of the area has a slope angle of $20-30^{\circ}$, except for a relatively flat valley floor at around $2020 \mathrm{~m}$ a.s.l. (Fig. 3). Until 1860, a part of this flat area was covered with a small shallow lake with subsurface discharge. During the construction of the pass road the lake accidentally drained; it could not be restored, and swampland remained. From 1944 to 1953, the swampland was drained and has since then been used first as farmland and later as hay meadow and pasture (Caflisch, 1954). 

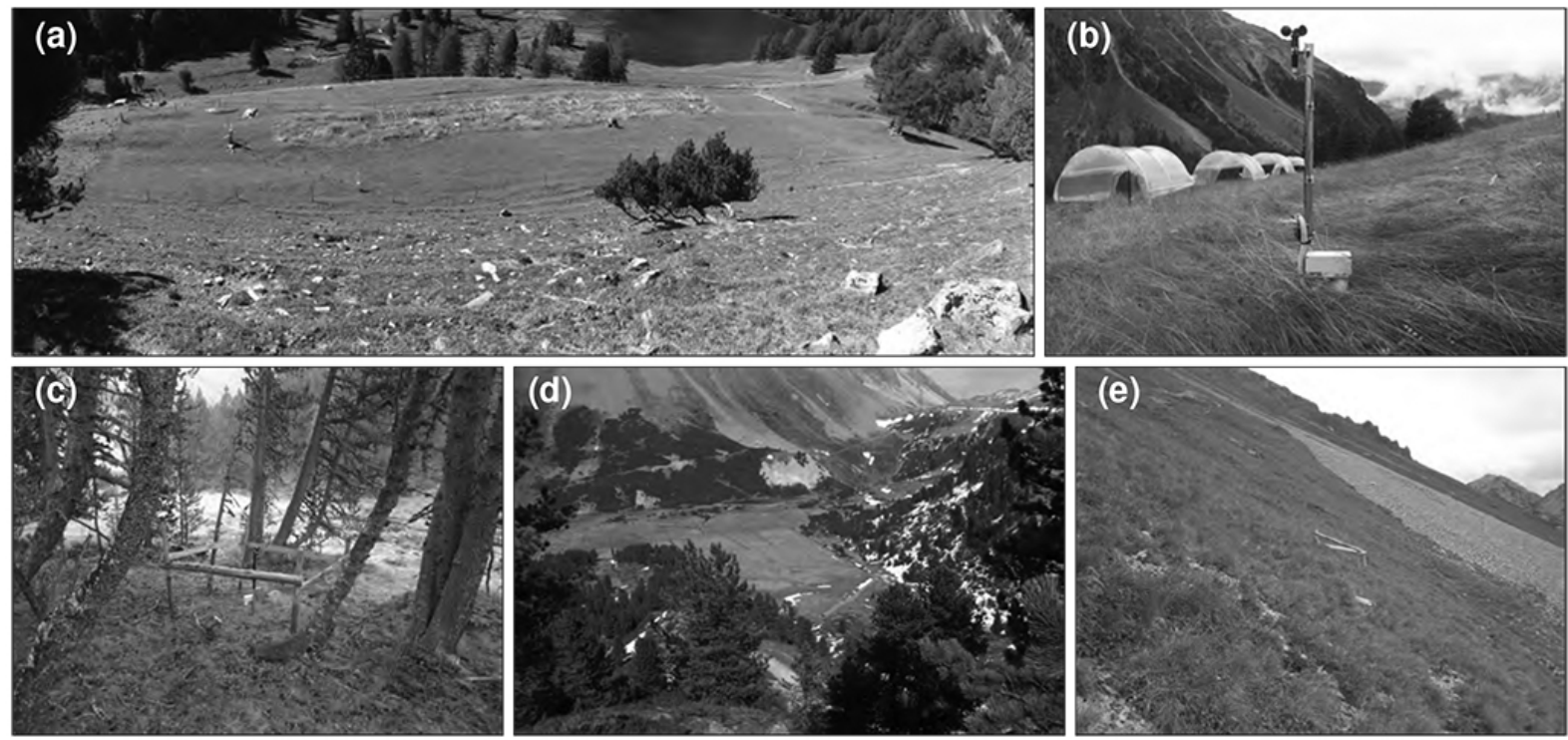

Figure 2. Alpine pastures of the Alp Weissenstein area. (a) Experimental plots for ecological climate change research (site 02a), view towards SW with Lai da Palpuogna in the background. (b) Close-up of near-surface measurements with a mini weather station at site 02a with rain exclusion shelters in the background. (c) Forest site 05b. (d) Valley floor with agrometeorological weather station in the center of the grassland surface and the Albula Pass in the upper right corner in ENE direction. (e) Scree slope site 08a (middle ground) and alpine grassland site $08 \mathrm{~b}$ (foreground).

Alp Weissenstein is located on a geological contact zone with whitish calcareous bedrock in the north, consisting of mesozoic sediments (biogenic sediment rocks, mostly dolomite and limestone). In the south, darker crystalline bedrock is found (mostly granite, Caflisch, 1954). A small inclusion of gypsum in the calcareous zone gave the name to this area (Crap Alv in Romansh; Alp Weissenstein in German, which both translate to White Rock in English). Coniferous forest is dominant in the southern part of the valley floor and in the western part of the site at altitudes below $2100 \mathrm{~m}$ (Fig. 3). This area is closely related to the extent of low-fertility soils on crystalline grounds. The area is dominated by grass vegetation, with scree vegetation or no vegetation in active scree zones. The southern part of the area is covered by forest and shrub vegetation.

\subsection{Design of the weather station network}

In order to characterize the topoclimatic variability within the domain of the research site, we installed a hierarchical network of weather stations during the growing season from mid-May to end of September 2005. This included two agrometeorological weather stations and 11 small stations. The agrometeorological weather stations were used to characterize the general climate of the Alp Weissenstein area, whereas the small weather stations were used to investigate the different microclimates. These sites were mostly chosen as paired sites at the same altitude, slope and exposition, but with different vegetation types, typically within a distance of $15-150 \mathrm{~m}$. With such a design the topographic influences are minimized between paired sites, whereas the comparison among all pairs allows for a more detailed topoclimatological assessment of plant growth conditions of the Alpine pastures and meadows.

The two agrometeorological weather stations were placed (1) near the center of the valley bottom where the former lake was located (2027 ma.s.l.) and (2) on a small plateau on the south-facing valley slope ( $2270 \mathrm{~m}$ a.s.l.), whereas the small weather stations were distributed over the entire area (see Fig. 3). Figure 2 shows selected examples of the different sites and the vegetation types.

The MeteoSwiss weather station at Samedan used for comparison is located south of the Samedan airport at an altitude of $1708 \mathrm{~m}$ a.s.l. in the Engadin Valley in a shallow depression, $8.5 \mathrm{~km}$ south-east of Alp Weissenstein. The MeteoSwiss station at Davos is located at the southern end of Lake Davos at $1594 \mathrm{~m}$ a.s.l. on a south-east oriented slope, around $30 \mathrm{~m}$ above the valley floor and $28 \mathrm{~km}$ north of Alp Weissenstein. For each of the two nearest valley bottom stations, we also selected their closest moutain peak station for comparison, which is Weissfluhjoch (2690 m a.s.l.) NW of Davos, and Piz Corvatsch (3305 ma.s.l.) SSW of Samedan (Fig. 1). 


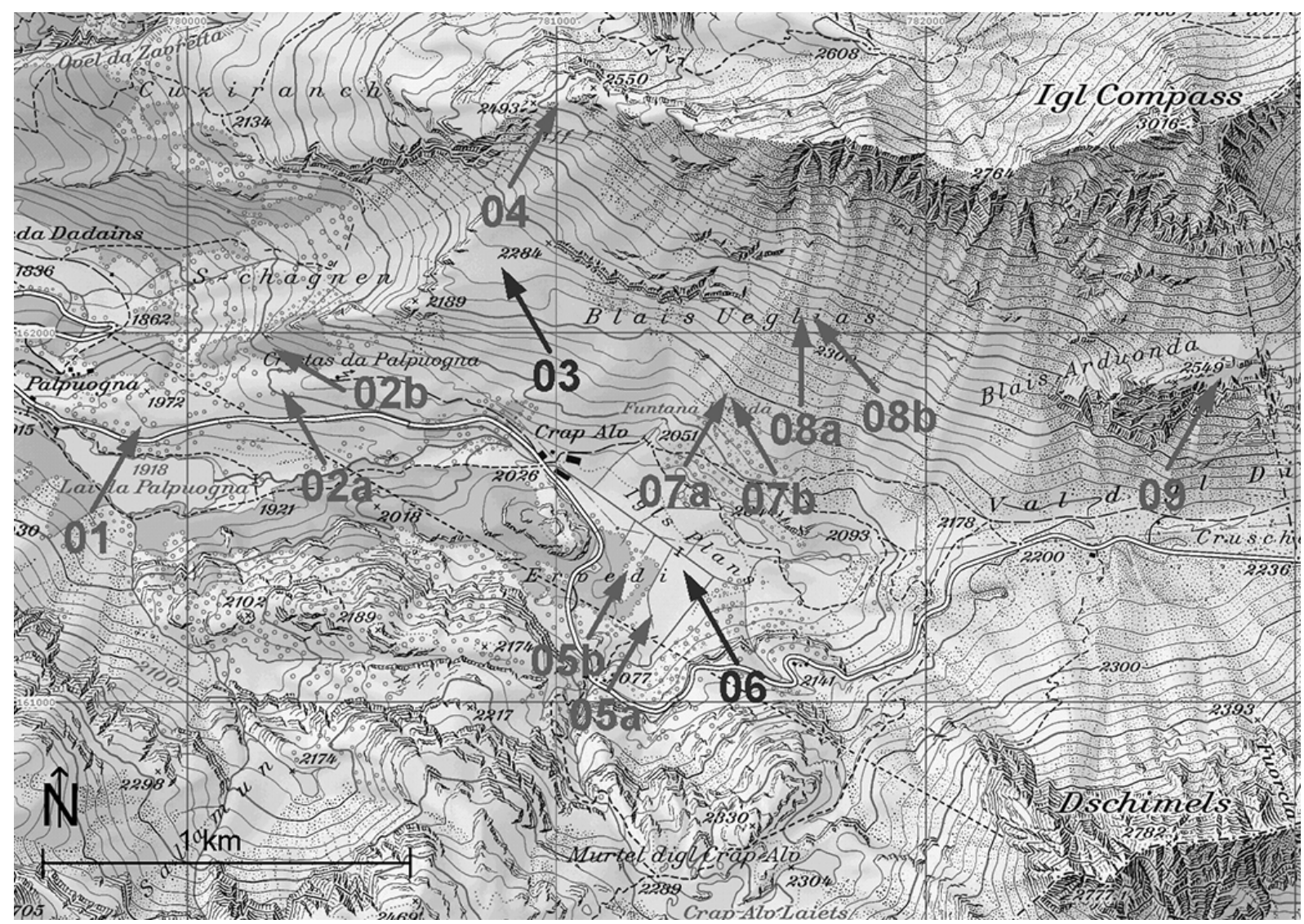

Figure 3. Location of the weather stations within the investigated area. The position of the agrometeorological weather stations (sites 03 and 06) is indicated with a blue arrow, the position of the stations for the near-surface measurements with red arrows. Reproduced by permission of swisstopo (C) 2011, JD100042/JA100120).

\subsection{Instrumentation}

\subsubsection{Agrometeorological weather stations}

We used weather stations for agricultural purposes (Markasub AG, Olten, Switzerland; see also http://www.agrometeo. ch), equipped with a sensor for air temperature and relative humidity (Hygroclip, Rotronic AG, Bassersdorf, Switzerland), a pyranometer (SP Lite, Kipp and Zonen, Delft, Netherlands), a pluviometer (LC, Texas Electronics, Dallas, USA), two sensors for leaf wetness (Lufft, Fellbach, Germany), and a combined sensor for grass and soil temperature $(5 \mathrm{~cm}$ above, respectively below ground; TB107 and TBMS1G, Rotronic AG, Switzerland). Measurements were made every $5 \mathrm{~s}$ using a CR10X datalogger (Campbell Scientific, UK) and stored as 10 min means or sums. Starting on 9 September 2005, the data storage interval was increased from 10 to $30 \mathrm{~min}$ to guarantee a longer station autonomy. On 25 September 2005, the boom with the sensors for air temperature, relative humidity, shortwave radiation, and precipitation was lifted from 2.0 to $2.5 \mathrm{~m}$ above ground to lower the risk that the mounted sensors and the solar panel get fully covered by snow during the winter.
For the comparison of the two sites at the valley bottom respective of the valley slope during summer/autumn 2005, the data coverage is $100 \%$; for the climatological overview at the site on the valley floor, the overall data coverage for the period 2006-2008 was $97.6 \%$; the detail shows $100 \%$ for all months except for November $(87.0 \%)$ and December $(84.2 \%)$. This is caused by two data gaps from 6 to 15 November 2007 (9.1 days) and from 28 November to 15 December 2008 (17.2 days).

\subsubsection{Near-surface measurements with small weather stations}

For the near-surface measurements we used small weather stations consisting of a cup anemometer (model f.555.1.18, Schiltknecht, Gossau, Switzerland; sensor height $100 \mathrm{~cm}$ above ground), and a combined sensor for air temperature and relative humidity (TRH 100, Pace Scientific Inc., Mooresville, N.C., USA; sensor height roughly $15-30 \mathrm{~cm}$ above ground). Radiation was measured with an amorph solar cell (Sunceram 2+, Conrad, Solothurn, Switzerland; sensor height $40 \mathrm{~cm}$ above ground) connected to a standard 
a)

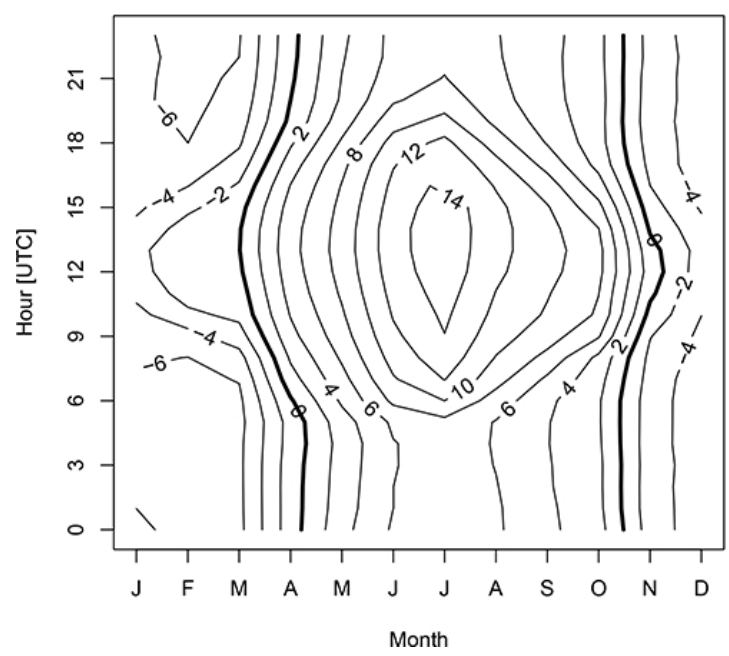

b)

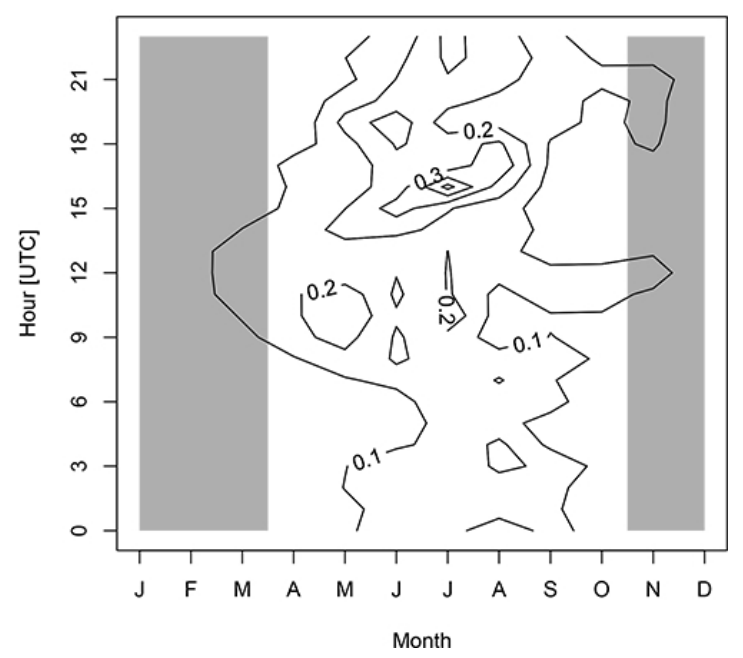

Figure 4. (a) Thermoisopleths diagram $\left(2{ }^{\circ} \mathrm{C}\right.$ increments) for the agrometeorological weather station 06 (valley floor) for the period $2006-$ 2008. (b) Same, but for the mean hourly precipitation sum $(0.1 \mathrm{~mm}$ increments). Gray shaded is the extended winter period where the unheated rain gauge is expected to malfunction.

resistor. These home-built low-cost sensors were intercalibrated with a standard pyranometer under ambient conditions (Fischer, 2005). The sensors were mounted on a $1.3 \mathrm{~m}$ aluminium mast, with the upper part painted black to minimize reflection. Measurements were done every 30 min using a XR 440 data logger (Pace Scientific Inc., Mooresville, N.C., USA). The stations were the same as those used by Vonlanthen et al. (2006a) and Vonlanthen et al. (2006b). After field deployment, all small weather stations were intercalibrated at the Chamau research site (Fig. 1) at $400 \mathrm{~m}$ a.s.l. (see e.g., Eugster and Zeeman 2006 for site details) with a recording interval of $2 \mathrm{~min}$.

Some small weather stations already failed shortly after installation, so that the net duration covered by all stations simultaneously is restricted to 13 summer days (24 June to 8 July 2005; see Table 1 for considerations on elevational gradients). In comparisons of paired sites, we used the period covered by both stations, which in the best case was 65 days (Sect. 3.6).

\section{Results and discussion}

In the following section the data of the different weather stations will be presented and interpreted. First, the focus is on the two agrometeorological weather stations. Second, the data of the near-surface measurements will be compared pairwise. Finally, an integrative overview over these findings will be given.

\subsection{Climatological overview January 2006- December 2008 of the valley floor}

A climatological overview on air temperature, grass temperature ( $5 \mathrm{~cm}$ above ground), soil temperature $(5 \mathrm{~cm}$ below ground), and precipitation during the three-year period is shown in Table 2. During five months (November-March), the monthly mean air temperature was below freezing, and during seven months (October-April) it was below $5^{\circ} \mathrm{C}$, a general threshold for plant growth (Körner, 2008). During the winter months (December-February), the mean daily maxima remained below $0^{\circ} \mathrm{C}$ (Fig. 4a). The monthly mean daily temperature range (DTR) is dominated by direct sun incidence, with only $2.5^{\circ} \mathrm{C}$ in December and up to $8.6^{\circ} \mathrm{C}$ in July.

For the three years, an average of 211.7 frost days (temperature falls below $0{ }^{\circ} \mathrm{C}$ ) and 76.3 ice days (temperature never exceeds $0{ }^{\circ} \mathrm{C}$ ) per year were recorded. From December to March almost all days had frost, and from December to February more than 15 days were also ice days. From May to September less than one ice day per month was seen, and the number of frost days was at a minimum in July (2 frost days per year).

During five months of the year (November-March), the daily average grass temperature was below $0{ }^{\circ} \mathrm{C}$ (Table 2). During all months, the average daily minima were below $5^{\circ} \mathrm{C}$, for six months even below the freezing point. The largest mean DTRs were observed during the summer months (JJA) with up to $16.9^{\circ} \mathrm{C}$, the smallest during winter with $0.1^{\circ} \mathrm{C}$. This clearly shows the isolating effect of the snow cover that can exceed $1 \mathrm{~m}$ in good winters and also explains why minimum grass temperatures in the winter are 
Table 1. Overview of data availability for the near-surface measurement sites (see also Fig. 3).

\begin{tabular}{|c|c|c|c|}
\hline Site & $\begin{array}{c}\text { Elevation } \\
\text { [m a.s.1.] }\end{array}$ & Period & Surface coverage \\
\hline 01 & 1955 & 23 Jun-9 Sep 2005 & Forest pasture \\
\hline $02 \mathrm{a}$ & 2005 & 22 Jun-8 Jul 2005 & Pasture $^{1}$ \\
\hline $02 b$ & 2005 & 22 Jun-9 Sep 2005 & Forest $^{2}$ \\
\hline 04 & 2510 & 21 Jun-25 Aug 2005 & Alpine grassland ${ }^{3}$ \\
\hline $05 \mathrm{a}$ & 2028 & 24 Jun-18 Aug 2005 & Meadow \\
\hline $05 b$ & 2035 & 22 Jun-19 Sep 2005 & Forest \\
\hline $07 \mathrm{a}$ & 2201 & 23-25 Jun 2005 & Pasture $^{1}$ \\
\hline 07b & 2199 & 22 Jun-25 Aug 2005 & Krummholz shrubland \\
\hline $08 \mathrm{a}$ & 2350 & 21 Jun-11 Jul 2005 & Scree slope ${ }^{1}$ \\
\hline $08 b$ & 2350 & 21 Jun-19 Jul 2005 & Alpine grassland ${ }^{4}$ \\
\hline 09 & 2540 & 22 Jun-25 Aug 2005 & Alpine grassland ${ }^{5}$ \\
\hline
\end{tabular}

${ }^{1}$ Destroyed by animals.

${ }^{2}$ Location changed by farmer.

${ }^{3}$ Missing humidity and radiation data from 10 August 2005, 08:00 UTC, onward.

${ }^{4}$ Destroyed, missing radiation data from 24 June 2005, 19:00 UTC, onward.

${ }^{5}$ Destroyed, missing radiation data from 16 August 2005, 17:30 UTC, onward.

often well above minimum air temperatures, when a snow cover is present (typically November-April).

Soil temperatures at $5 \mathrm{~cm}$ depth varied from -0.4 to $14.1^{\circ} \mathrm{C}$ with a mean value of $4.4^{\circ} \mathrm{C}$ (Table 2 ). Average DTRs were generally small with largest values during summer (up to $1.1^{\circ} \mathrm{C}$ ) and almost inexistent in the winter. During January to March, the mean soil temperature was around $0^{\circ} \mathrm{C}$, which is considered the expected basal temperature under a good isolating snow pack in the absence of permafrost (Haeberli, 1973).

Precipitation was measured during all months. As expected, the data show more precipitation during summer (up to $155.9 \mathrm{~mm}$ per month) than during the transition seasons (roughly 50-100 mm per month). The mean annual sum of $810.8 \mathrm{~mm}$ of liquid precipitation is roughly $0.5-0.8$ times the amount of total precipitation interpolated from long-term data for the region (SMA, 1984). In Fig. 4b the mean hourly precipitation intensities for spring, summer, and autumn are shown. Most remarkable is the peak of roughly $0.3 \mathrm{~mm} \mathrm{~h}^{-1}$ between 15:00 and 18:00 UTC (17:00-20:00 CEST) during the summer months, which is most likely caused by the typical (afternoon) convective showers and thunderstorms. Precipitation intensity in all months was higher during the day than at night; however, frozen precipitation during winter could not be measured due to the use of an unheated rain gauge (only in November 2012 was a heated rain gauge installed for future studies).

Since the nearest MeteoSwiss ANETZ/SMN weather station at Samedan is located only $8 \mathrm{~km}$ to the southeast, a relatively good agreement between our station at Alp Weissenstein and Samedan could be expected. This is however only partially the case. Figure 5 shows pairwise scatter plots of the hourly mean air temperature of Alp Weissenstein, Samedan and Davos. During winter, the data show a rather poor agreement between Alp Weissenstein and Samedan $\left(R^{2}=0.41\right)$. For values below $-10^{\circ} \mathrm{C}$, a substantial shift towards lower temperatures in Samedan was observed, whereas for Davos, no such pattern was found and the agreement was better $\left(R^{2}=0.67\right)$. The question is whether cold-air accumulation on the valley bottom is a key factor for climatic similarities between Alp Weissenstein and surrounding MeteoSwiss stations, hence we also made a correlation analysis that includes the corresponding mountain peak sites Corvatsch (near Samedan) and Weissfluhjoch (near Davos) (Fig. 6). In all months the best agreement of Alp Weissenstein mean temperatures (hourly resolution) was found with Davos (Fig. 6a), with $R^{2}$ typically $>0.8$ during the warm season, but clearly with lower values in the winter. Even during a selected winter month (January, Fig. 6b) and summer month (June, Fig. 6c), Davos was the closest long-term meteorological station for all hours of the day. Only in the summer were the two mountain top stations and Davos similarly correlated with the diurnal course of temperature at Alp Weissenstein, whereas Samedan, the closest station, was much more affected by cold air pooling during nighttime hours (01:00-05:00 UTC, Fig. 6c), which is seen in a clearly lower $R^{2}$ than during daytime hours. For a long-term characterization of the climate at Alp Weissenstein it is hence recommended to use the Davos data.

\subsection{Intercomparison between agrometeorological weather stations (sites 06 and 03)}

During the period 21 June to 25 August 2005 (65 days), both agrometeorological weather stations on the valley bottom meadow (site 06; at $2027 \mathrm{~m}$ a.s.l.) and on the plateau on the southerly exposed slope (site 03; at $2270 \mathrm{~m}$ a.s.1.) were operational (Fig. 3). Mean temperature at the higher location was $8.6^{\circ} \mathrm{C}$ and $9.4^{\circ} \mathrm{C}$ at the lower one (Fig. 7a), resulting in a mean temperature gradient of $-0.36^{\circ} \mathrm{C} / 100 \mathrm{~m}$. The hourly mean temperatures ranged between 6.4 and $11.2^{\circ} \mathrm{C}$ (absolute range -2.4 to $21.2^{\circ} \mathrm{C}$ ) at site 03 and 5.9 to $13.3^{\circ} \mathrm{C}$ at site 06 (absolute range -2.4 to $23.2^{\circ} \mathrm{C}$ ). During daytime the temperatures at site 06 (valley floor) are nearly constantly $2.0^{\circ} \mathrm{C}$ higher $\left(-0.82^{\circ} \mathrm{C} / 100 \mathrm{~m}\right)$ than at site 03 (plateau), and during nighttime they are almost constantly $0.5^{\circ} \mathrm{C}$ lower $\left(+0.21^{\circ} \mathrm{C} / 100 \mathrm{~m}\right)$ (Fig. 7a), which is in agreement with the expectation of catabatic drainage flows bringing cold air to the valley bottom where it is pooled at night.

The diurnal cycle of the water vapor pressure deficit (VPD; Fig. 7c) is more pronounced at site 06 on the valley bottom (mean diurnal range 0.9 to $7.2 \mathrm{hPa}$ ) than at the higher elevated site (2.2 to $5.7 \mathrm{hPa}$; Fig. 7c), direcly following the respective diurnal cycle of air temperature. During nighttime, VPD is around $1 \mathrm{hPa}$ higher at the higher elevated site 03 , and around $1.5 \mathrm{hPa}$ lower during daytime, indicating less probability of dew formation at higher than lower elevations. As expected, the regime change occurs during the times of sunrise and sunset. 
Table 2. Climatological overview on air temperature $\left(T_{\text {Air }}\right)$, grass temperature $\left(T_{\text {Grass }}\right)$, soil temperature $\left(T_{\text {Soil }}\right)\left[{ }^{\circ} \mathrm{C}\right]$, precipitation sum [mm], mean number of frost days (FD), and mean number of ice days (ID) measured at site 06 during the period January 2006-December 2008. Mean daily minima, daily means, and maxima are given for temperature, and the monthly extreme values are indicated in brackets. Between October to March the rain gauge is expected to freeze, thus the noted values only represent liquid precipitation and thus are expected to underestimate total precipitation.

\begin{tabular}{|c|c|c|c|c|c|c|c|c|c|c|c|c|c|c|c|}
\hline Month & $\min$ & mean & $\begin{array}{l}T_{\text {Air }} \\
\max \end{array}$ & (range) & $\min$ & mean & $\begin{array}{r}T_{\text {Grass }} \\
\max \end{array}$ & (range) & $\min$ & mean & $\begin{array}{c}T_{\text {Soil }} \\
\max \end{array}$ & (range) & $\begin{array}{r}\text { Precip } \\
\text { sum }\end{array}$ & FD & ID \\
\hline Jan & -6.3 & -5.2 & 2.3 & $(-22.4-8.8)$ & -1.9 & -1.7 & -1.6 & $(-8.2--0.1)$ & 0.3 & 0.3 & 0.3 & $(-0.4-0.7)$ & 8.0 & 30.7 & 18.0 \\
\hline Feb & -7.0 & -5.0 & -0.3 & $(-23.6-9.9)$ & -1.2 & -1.1 & -1.1 & $(-3.8--0.1)$ & 0 & 0.3 & 0 & $(-0.2-($ & 4.6 & 28.0 & 15.0 \\
\hline Mar & -6.6 & -4.2 & -0.1 & $(-27.8-10.3)$ & -0.5 & -0.4 & -0.4 & $(-1.2--0.1)$ & 0.4 & 0.4 & 0.4 & $(-0.1-1.0)$ & 27.5 & 30.7 & 11.7 \\
\hline Apr & -1.3 & 1.6 & 5.3 & $(-16.8-15.3)$ & -0.3 & 0.9 & 3.1 & $(-4.4-32.1)$ & 0.9 & 1.0 & 1.1 & $(-0.4-$ & 49.8 & 22.3 & 4.0 \\
\hline May & 2.7 & 5.6 & 8.9 & $(-7.0-18.1)$ & 1.1 & 6.0 & 14.2 & $(-8.1-41.3)$ & 4.5 & 4.9 & 5.3 & $(0.0-9.8)$ & 105.7 & 10.3 & 0.3 \\
\hline Jun & 5.8 & 9.4 & 13.3 & $(-5.5-22.6)$ & 4.4 & 10.8 & 21.3 & $(-9.1-45.8)$ & 8.6 & 9.1 & 9.7 & $(4.1-13.8)$ & 118.7 & 4.3 & 0.0 \\
\hline Jul & 6.9 & 11.1 & 15.5 & $(-3.9-23.2)$ & 5.0 & 11.4 & 21.3 & $(-6.7-37.3)$ & 10.3 & 10.8 & 11.2 & $(6.7-14.1)$ & 155.9 & 2.0 & 0.0 \\
\hline Aug & 5.8 & 8.8 & 12.7 & $(-1.6-21.5)$ & 5.3 & 9.4 & 16.7 & $(-5.0-27.3)$ & 9.6 & 9.9 & 10.3 & $(7.1-13.6)$ & 136.3 & 2.7 & 0.0 \\
\hline Sep & 4.1 & 6.7 & 10.8 & $(-5.8-22.3)$ & 3.4 & 6.6 & 13.9 & $(-5.4-27.8)$ & 7.7 & 8.0 & 8.2 & (4.1-11.4) & 83.6 & 12.3 & 0.7 \\
\hline Oct & 2.2 & 4.2 & 8.7 & $(-11.3-16.8)$ & 0.6 & 2.7 & 8.6 & $(-8.6-21.6)$ & 4.8 & 5.0 & 5.1 & $(2.1-9.7)$ & 46.7 & 18.0 & 2.3 \\
\hline Nov & -3.2 & -2.1 & 1.2 & $(-21.7-12.2)$ & -1.7 & -1.0 & 0.6 & $(-14.3-10.1)$ & 1.6 & 1.6 & 1.7 & $(0.3-5.0)$ & 53.5 & 23.4 & 8.2 \\
\hline Dec & -5.3 & -4.6 & -2.8 & $(-22.0-6.6)$ & -1.3 & -1.2 & -1.1 & $(-5.2-2.1)$ & 1.0 & 1.0 & 1.0 & $(0.3-1.9)$ & 9.6 & 29.8 & 18.3 \\
\hline Year & 0.0 & 2.4 & 6.1 & $-27.8-23.2)$ & 1.2 & 3.7 & 8.2 & ( & 4.3 & . & ... & 形 & 810.8 & 211.7 & 76.3 \\
\hline
\end{tabular}

The grass temperature (sensor $5 \mathrm{~cm}$ above ground; not represented in Fig. 7) behaves similar to air temperature: the DTR is more pronounced at the higher elevated site 03 than at site 06 on the valley floor, which is a result of stronger insolation of the southerly exposed slope where site 03 is located, in combination with the very different heat capacities of the underlying soil surfaces. During nighttime, the values at site 06 are around $2{ }^{\circ} \mathrm{C}$ higher $\left(5.1\right.$ and $3.0^{\circ} \mathrm{C}$ at sites 06 and 03 , respectively), and $2-3{ }^{\circ} \mathrm{C}$ lower during daytime (20.9 and $23.1^{\circ} \mathrm{C}$ ). This is consistent with the buffering effect of the high-organic soil with a high soil water content at the valley bottom site vs. the rocky and much drier soil at site 03 . Soil temperature (not shown) shows for both sites a nearly identical diurnal cycle with a small amplitude of $1.1^{\circ} \mathrm{C}$, with the minimum at 11:00 CET and the maximum at 20:00 CET. The soil temperature at $5 \mathrm{~cm}$ depth was $1.0^{\circ} \mathrm{C}$ lower at site $03\left(9.4^{\circ} \mathrm{C}\right)$ than at site $06\left(10.4^{\circ} \mathrm{C}\right)$.

Shortwave incoming radiation is very similar at the two sites, although instantaneous differences of up to $600 \mathrm{~W} \mathrm{~m}^{-2}$ are observed under conditions with variable local cloud cover. The difference of about $-100 \mathrm{~W} \mathrm{~m}^{-2}$ at the elevated station shortly after sunrise is caused by the different horizon as a result of topography. All other differences are $<50 \mathrm{~W} \mathrm{~m}^{-2}$ and mostly randomly distributed over the day.

Precipitation data look very similar with respect to the timing of the events, the maximum intensities (up to $6 \mathrm{~mm} / 10 \mathrm{~min}$ ) are found simultaneously at both sites. However, the cumulative sum over the whole period of 65 days differs substantially with $271 \mathrm{~mm}$ at site 03 and $156 \mathrm{~mm}$ at site 06 (Fig. 7b). As was expected, precipitation increased with altitude.

Ekhardt (1948) and Baumgartner et al. (1983) mention an altitudinal precipitation gradient for annual totals of $P_{h}=68 \mathrm{~mm} / 100 \mathrm{~m}$ for the Eastern Alps; similar values were found by Schüepp et al. (1978). However, precipitation measurements above $2500 \mathrm{~m}$ a.s.l. are rare and thus the determination of such gradients remains difficult. Further, geographical variations are expected. Sevruk (1985) quantified the bias in precipitation measurements for the Swiss Alps at $2-10 \%$ for rain, $10-50 \%$ for snow, and for other effects up to $10 \%$ underestimation. Caflisch (1954) noted that since August 1923 there are precipitation measurements at the Albula Pass (Hospiz), but he also states that the wintertime data are far below the experienced values of the inner Alps. It remains however unclear which part of this difference can be attributed to inadequate coverage of snowfall (as with our unheated raingauge) and which part reflects reality. During our station visits in the winter, we recorded snow heights of 40$60 \mathrm{~cm}$ in December and February on an irregular basis. This snowpack adds roughly $80-120 \mathrm{~mm}$ of liquid precipitation when assuming a water equivalent of 0.2. This is much larger than the recorded sums of $22.2 \mathrm{~mm}$ for December to February and $75.7 \mathrm{~mm}$ including November (see also Table 2).

In this case-study we only can address the differences in liquid precipitation, thereby excluding the winter aspects. We would expect about $30 \mathrm{~mm}$ more precipitation at the higher elevated site 03 compared to site 06 on the valley floor when scaling the altitudinal precipitation gradient given by Ekhardt (1948) and Baumgartner et al. (1983) to our sampling period of 65 days. But we measured a much larger difference of $115 \mathrm{~mm}$. Until 21 August, the 61st day of our measurements, the difference between the stations followed the expected gradient. However, during the last four days of our measurements, a dramatic increase was observed. As the recorded difference of $115 \mathrm{~mm}$ is very unlikely the product of a meteorological event, even though thunderstorms with heavy precipitation were reported for those days (MeteoSchweiz, 2005), it might be caused by sensor problems 

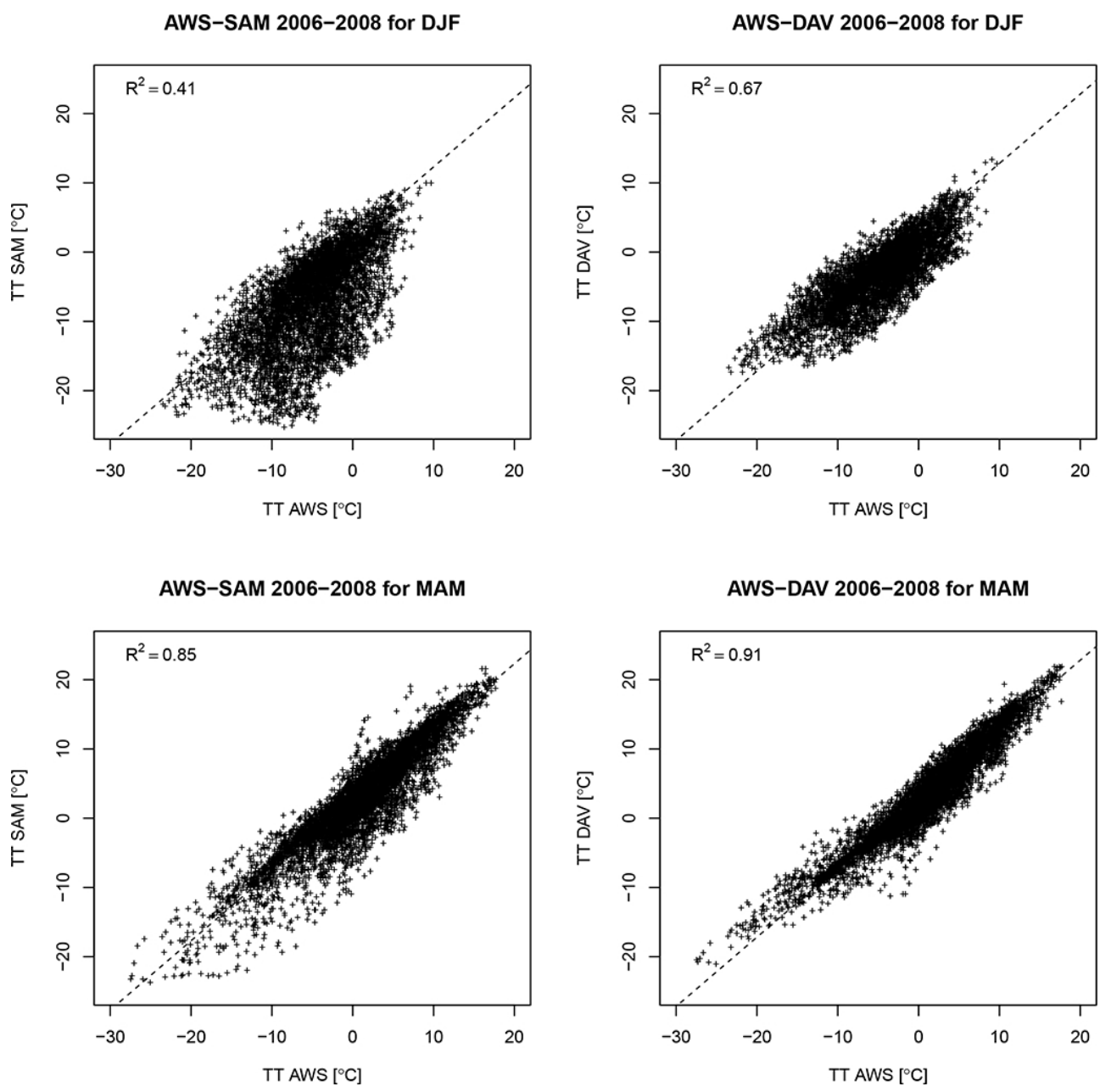

Figure 5. Comparison between hourly mean temperatures of the period 2006-2008 for the agrometeorological weather station 06 (valley floor) at Alp Weissenstein (AWS) and the MeteoSwiss ANETZ/SMN stations Samedan (SAM) and Davos (DAV). The upper part shows the winter data (DJF), the lower part the data for spring (MAM). The $1: 1$ lines are shifted using an altitudinal gradient of $0.65^{\circ} \mathrm{C} / 100 \mathrm{~m}$.
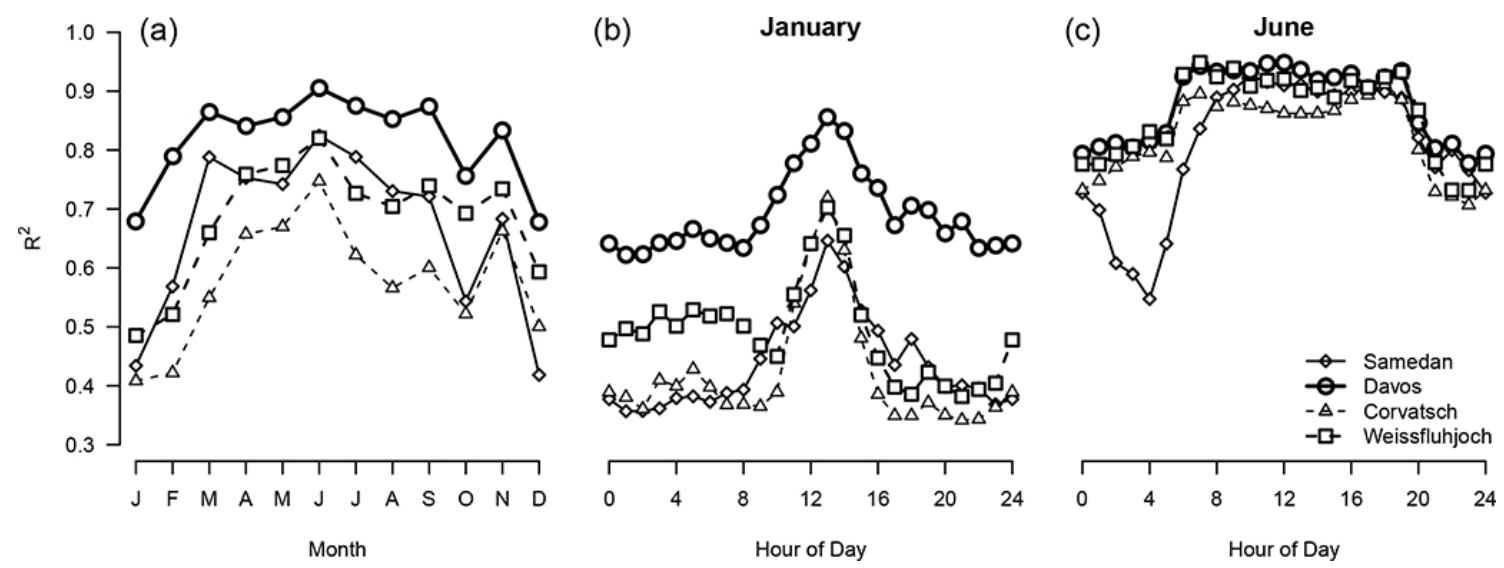

Figure 6. Coefficients of determination between temperature measurements and nearby long-term meteorological sites. $R^{2}$ for hourly data aggregated (a) for each month, and (b, c) for each hour of day during January (b) and June (c). Samedan and Davos are valley bottom stations, Corvatsch and Weissfluhjoch are the corresponding mountain top stations. 
a)

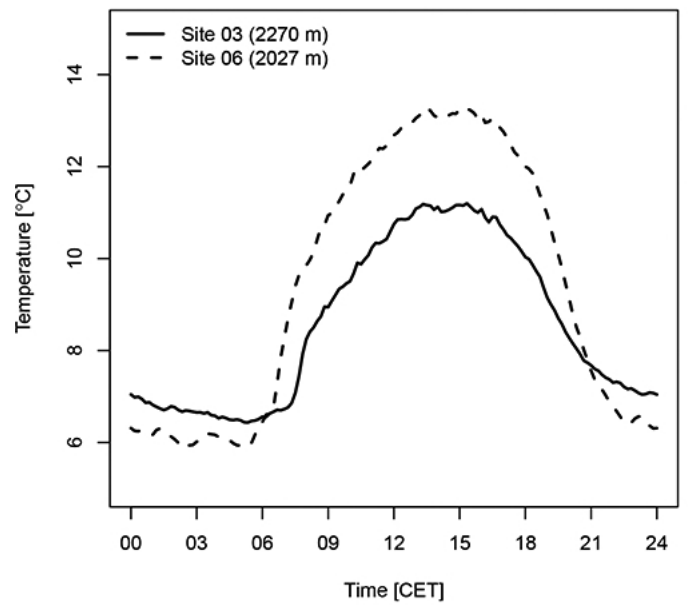

c)

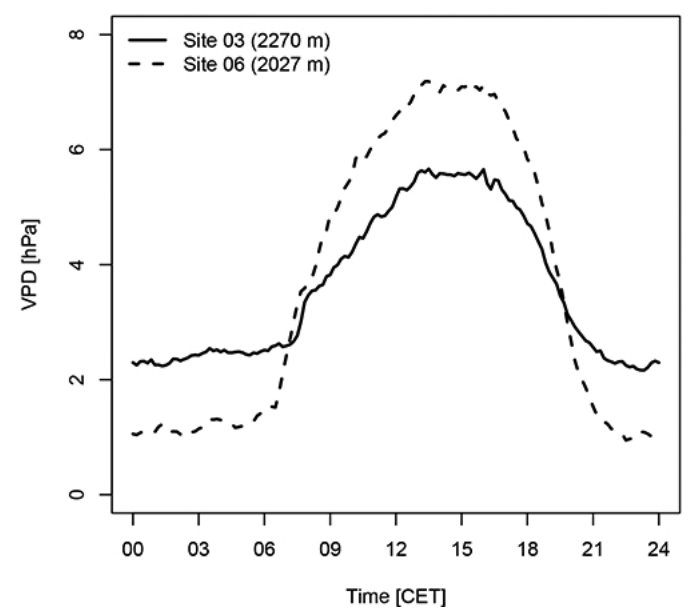

b)

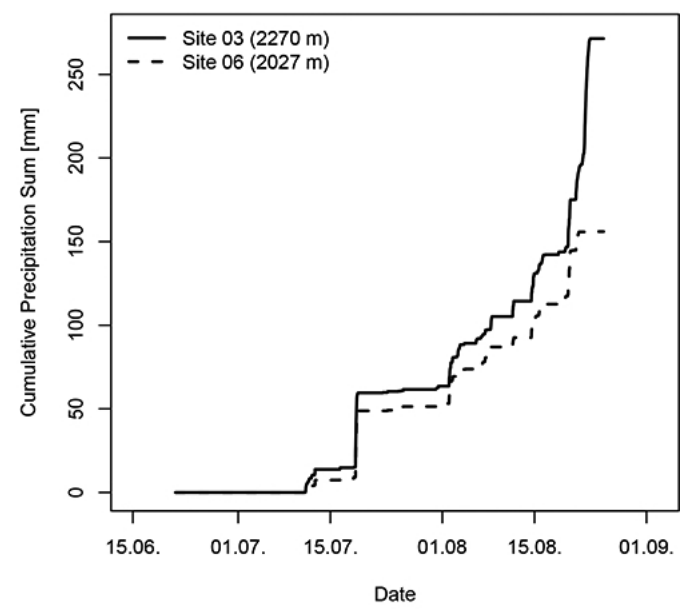

d)

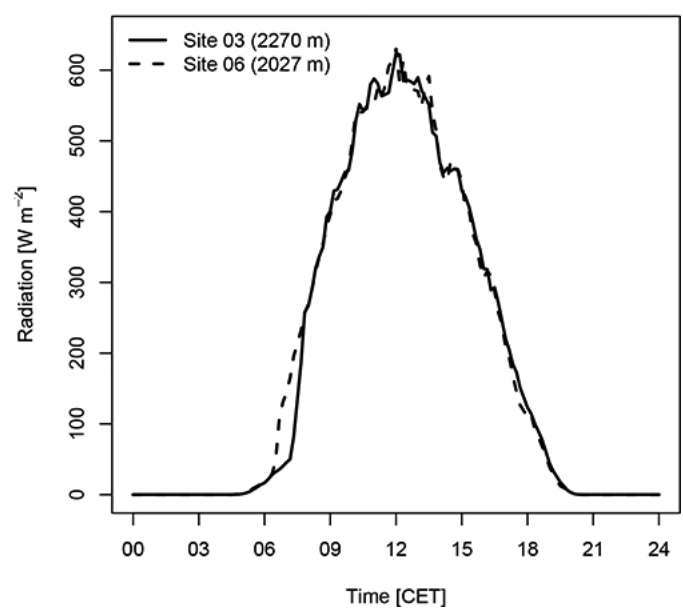

Figure 7. Mean diel cycles of the agrometeorological weather stations for (a) air temperature, (b) cumulative precipitation sum, (c) water vapor pressure deficit (VPD), and (d) global radiation for the period 21 June 2005, 12:30 CET to 25 August 2005, 12:20 CET.

at the higher station. Thus, we rejected these last four days of the measuring period (from 21 August 2005, 18:00 UTC on). The amounts change to $193.2 \mathrm{~mm}$ for the higher (03) and $155.8 \mathrm{~mm}$ for the lower (06) located site with a gradient of $15.4 \mathrm{~mm} / 100 \mathrm{~m} / 65$ days. During the same period, the nearest MeteoSwiss precipitation gauges north of the Albula Pass measured $211.3 \mathrm{~mm}$ at Tiefencastel (892 ma.s.l.) and $281.1 \mathrm{~mm}$ at Filisur (1030 m a.s.1.). Unfortunately, the closest station at Latsch (1610 m a.s.l.) was out of order during our entire case-study period. Still, the vertical gradient of $16.5 \mathrm{~mm} / 100 \mathrm{~m} / 65$ days between Tiefencastel and Filisur is very similar to what was measured at Alp Weissenstein. A comparison of monthly totals measured at site 06 (which was continued after installation in late June 2005) with the nearest MeteoSwiss raingauges (Fig. 8) clearly shows that, despite the increased altitude, Alp Weissenstein is typically receiving similar amounts of precipitation as lower sites during the summer months. If one expects that an extrapolation of the precipitation gradient from lower stations to Alp Weissenstein is a valid reference, then our measurements indicate a comparatively dry climate at Alp Weissenstein: extrapolating the Filisur precipitation to Alp Weissenstein for the short period where both sites 03 and 06 were operational would suggest $398 \mathrm{~mm}$ during said summer period, whereas true readings were $242 \mathrm{~mm}$ or $60 \%$ lower. Figure 8 , indeed, shows that the summer 2005 period was receiving a surprisingly low amount of precipitation at Alp Weissenstein, whereas in the following years no systematical low reading could be detected. However, April, May and June 2008 clearly show that there can be periods where the precipitation regime at Alp Weissenstein clearly differs from the lower 




Figure 8. Comparison of monthly totals of liquid precipitation measured at Alp Weissenstein (2027 m a.s.1.) 2005-2008 with total precipitation (liquid plus melted snow) measured at Tiefencastel (892 ma.s.1.), Filisur (1030 ma.s.1.), Alvaneu (1170 m a.s.1.), and Latsch (1610 m a.s.1.).

sites further north. Only long-term measurements will allow a more detailed assessment of such effects.

The nighttime temperature difference between the midslope and the valley bottom station show the expected effect of cold air accumulation in valleys and topographic depressions that are fed by catabatic drainage flows down the slopes of the valley that starts in the early evening (around 17:00 18:00 according to our temperature measurements presented in Fig. 7a) and is part of the local valley wind system.

Urfer (1981) reported an inversion height of several $100 \mathrm{~m}$ above valley bottom, whereas our data indicate a lower height. The cold air will flow out hydrostatically because there is no damming as it is likely to occur at the lower end of the Dischma Valley, which joins the Landwasser Valley at Davos. Apart from a larger DTR at the valley floor compared to the slopes (see also Whiteman 1982), our results are qualitatively similar to the climatological study of the Dischma Valley (Urfer, 1981).

The sky view factor is clearly larger at the upper station which enhances long-wave radiation losses as compared to the valley bottom site. Midday temperatures at the upper site are roughly $2.0^{\circ} \mathrm{C}$ lower than on the valley bottom, showing a gradient of $-0.83{ }^{\circ} \mathrm{C} / 100 \mathrm{~m}$. This high gradient could also result from a convective layer developing by anticyclonic situations over the bottom of the valley, which could however not be investigated in all detail.

The seasonal cycle in solar radiation input is also well seen in the diurnal temperature cycle of the continuous $3 \mathrm{yr}$ measurements at site 06, which is more pronounced during summer than in the winter (not shown). Approximately from December to January the weather station 06 and the southern part of the valley bottom do not receive direct sunlight and the temperature changes are hence only caused by advection. Site 03 (upper station) has a later sunrise than site 06 (valley floor) because the slope on which the station is located is fac- ing to SSW, and lies in the shadow of close-by Igl Compass (Fig. 3) early in the morning (Fig. 7d).

\subsection{Pasture-forest contrasts at lower altitude ( $\approx 2000$ m a.s.l., sites $02 a$ and $02 b$ )}

The temperature differences between sites $02 \mathrm{a}$ and $02 \mathrm{~b}$ (lower pasture and coniferous forest) can mainly be characterized by a steeper increase during the morning and generally $2-5{ }^{\circ} \mathrm{C}$ higher maximum values (Fig. 9a). Cooling in the forest starts earlier in the evening, but at a lower rate than on the pasture. The minima in the forest are typically (but not always) slightly higher than on the pasture. During the period from 23 to 28 June 2005 air temperatures ranged from 8 to $30{ }^{\circ} \mathrm{C}$.

Humidity (calculated as water vapor pressure deficit, VPD) is slightly lower at the forest site than at the pasture site during nighttime (VPD is around $3 \mathrm{hPa}$ at both sites; Fig. 9b). During daytime the VPD is with a peak value of $16 \mathrm{hPa}$ roughly $5 \mathrm{hPa}$ higher at the pasture site than at the forest site. The differences are largest around sunrise (up to $8 \mathrm{hPa}$ ).

Radiation at the pasture site yielded maximum values in the range $900-1050 \mathrm{~W} \mathrm{~m}^{-2}$ on clear days, whereas typical values for the forest site were $100-900 \mathrm{~W} \mathrm{~m}^{-2}$ close to the forest floor (Fig. 9c). The highest values were generally of short duration, which can be explained by an occasional direct view of the sun whenever the station was covered by a sunfleck. The wind speed does not, in most cases, exceed $15 \mathrm{~m} \mathrm{~s}^{-1}$ at the pasture, and $5 \mathrm{~ms}^{-1}$ in the forest. Maximum wind speeds were normally higher during the day, but also hourly mean wind speeds peaked in the afternoon (Fig. 9d), when the up-valley wind is active (see also Hiller et al., 2008). Up-valley winds mostly affect the valley bottom (see e.g., Whiteman, 2000) rather than higher elevations, but 


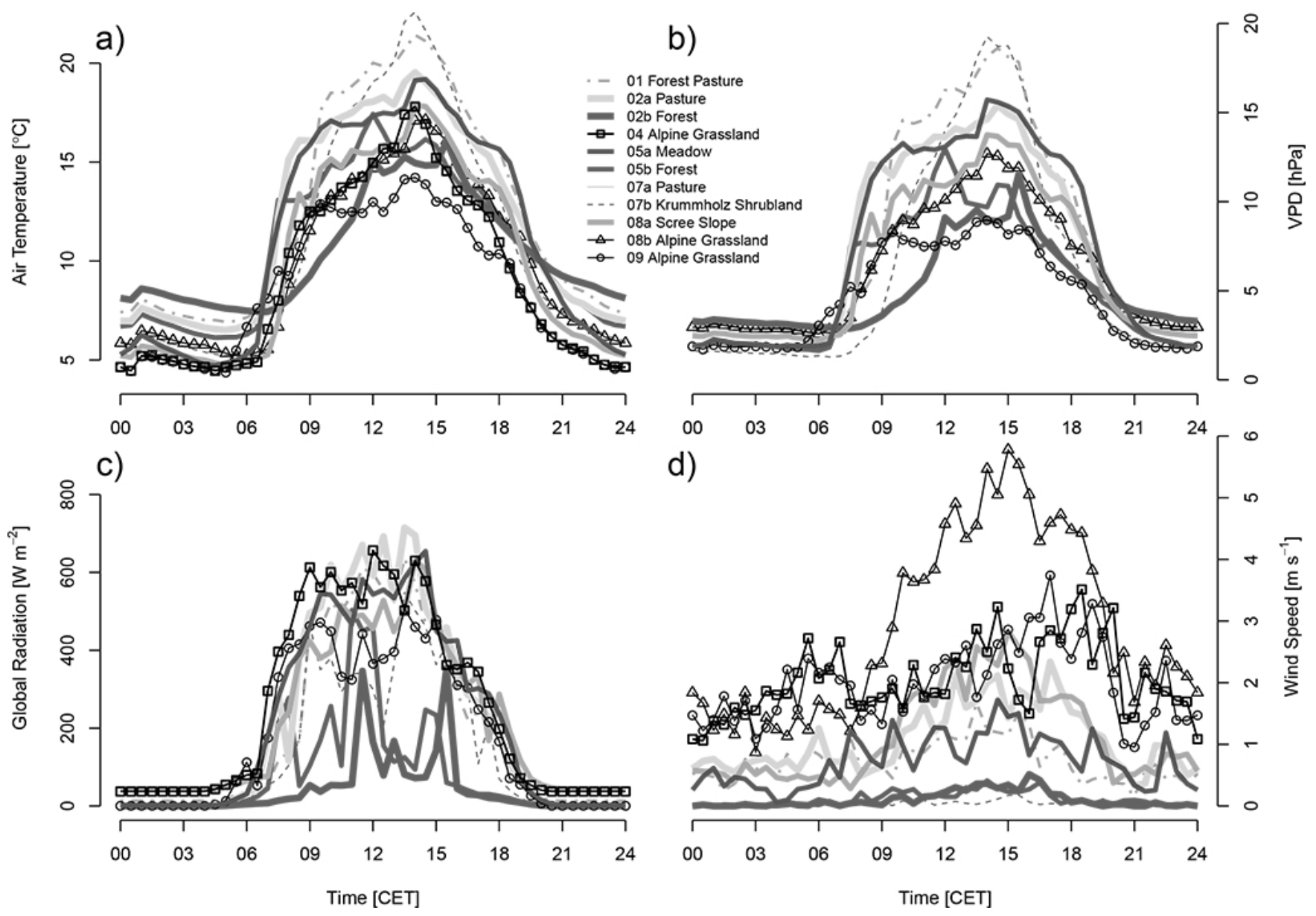

Figure 9. Mean diel cycles of the near-surface measurement sites for (a) air temperature, (b) water vapor pressure deficit (VPD), (c) incoming shortwave radiation, and (d) wind speed for the period 25 June 2005, 01:00 CET to 8 July 2005, 00:30 CET. See also Table 1 for the description of the site locations.

the highest wind speeds are usually measured 100 or $200 \mathrm{~m}$ above the bottom of the valley and not on the valley floor at one or several meters above the ground. Hence, the highest wind speeds are measured during the afternoon on wellexposed slopes with alpine grasslands at about $300 \mathrm{~m}$ above the bottom of the Albula valley (site 08b) and they are a little weaker higher in elevation (sites 04 and 09). Wind speeds are a little higher on pastures (or meadows) at the bottom of the valley at lower $(2000 \mathrm{~m}$ a.s.l.: sites 01 and $02 \mathrm{a}$, see Fig. 9d) rather than intermediate ( $2050 \mathrm{~m}$ a.s.l.: site $05 \mathrm{a})$ altitude, probably because the Albula valley is narrower at a lower altitude (Alp Weissentein). As expected, wind speeds are much lower in forest than pastures or meadows at the same elevation. They are also weaker on shrublands or scree slopes than alpine grasslands at the same location due to higher ground roughness. In general, all sites show the clear diurnal pattern that is typical for the top portions of a valley wind system, with well-developed up-valley winds during the day, but very weak down-valley winds at night because of the lack of a large hinterland that could produce massive volumes of cold air to support a strong nocturnal down-valley wind.

\subsection{Pasture-forest contrasts at intermediate altitude $(\approx 2050$ m a.s.I., sites 05a and 05b)}

Both temperature time series show a clear diurnal cycle (Fig. 9a). Similar to the lower pasture-forest station pair, a faster temperature increase is found on the pasture, and a slower temperature decrease in the afternoon in the forest. The temperature maxima at the pasture are reached in late afternoon, whereas at the forest site the maximum level is reached earlier. Generally, the daily maxima are around $3{ }^{\circ} \mathrm{C}$ higher on the pasture, and the minima are $1-3^{\circ} \mathrm{C}$ lower. The daily means are roughly $0.6^{\circ} \mathrm{C}$ higher on the pasture.

VPD at both sites is almost identical at around $2 \mathrm{hPa}$ during nighttime and the first hour after sunrise. During the afternoon VPD at the pasture site reaches its maximum with $19 \mathrm{hPa}$, whereas the maximum at the forest site $(13 \mathrm{hPa})$ occurs during late morning (Fig. 9b). 
Radiation at the pasture site typically reaches a maximum value of $900-1000 \mathrm{~W} \mathrm{~m}^{-2}$, on clear days, whereas the maximum value at the forest site is around $50 \mathrm{~W} \mathrm{~m}^{-2}$ higher than at the pasture site but usually of much shorter duration. On a daily basis, the incoming radiation budget on the pasture is normally between 55 and $75 \%$ higher than in the corresponding forest (Fig. 9c). Wind speeds of 2.75-5.5 $\mathrm{m} \mathrm{s}^{-1}$ are generally higher on the pasture compared to the forest $(0.5-$ $\left.1.5 \mathrm{~m} \mathrm{~s}^{-1}\right)$. The corresponding average daily wind speeds are $0.25-1.5 \mathrm{~m} \mathrm{~s}^{-1}$ and $<0.25 \mathrm{~m} \mathrm{~s}^{-1}$ (Fig. 9d).

\subsection{Debris cone-grassland contrasts $(\approx 2350$ m a.s.I., sites 08a and 08b)}

Both temperature time series showed a clear diurnal cycle with an amplitude between 6 and $22^{\circ} \mathrm{C}$. However, compared to the previously discussed station pairs, the observed differences between these two sites are unexpectedly small (Fig. 9a), despite the very different surface reflectivity, soil heat capacity and plant activity. The maxima differ roughly by $0-2{ }^{\circ} \mathrm{C}$. During the first part of our measuring period the grassland site showed higher maxima, later in the season (with lower solar elevation angle) it was the site in the debris cone. The largest differences of up to $6^{\circ} \mathrm{C}$ are found during the morning hours with grassland being warmer than the debris. In nearly all cases, the minima of the grassland site are between 0.5 and $1.5^{\circ} \mathrm{C}$ higher than on the debris cone. On the daily scale, the differences are within the $\pm 0.5^{\circ} \mathrm{C}$ absolute accuracy of the sensors. This finding was not expected since the almost vegetation free debris cone is not subject to transpiration cooling as is expected over grassland. However, our measurements suggest that either there is sufficient moisture between the debris to allow for evaporative cooling of the surface, or the whitish color of the calcareous rocks reflects sufficient solar radiation in such a way that the debris cone surface cannot heat up significantly above the level observed over the much darker grass.

VPD values are very similar at both sites (Fig. 9b). During nighttime VPD is $0.5 \mathrm{hPa}$ lower at the debris cone site $(2.5 \mathrm{hPa})$, whereas during daytime VPD is up to $2 \mathrm{hPa}$ higher (maximum $14 \mathrm{hPa}$ during noontime).

Radiation data were only available for three days after which the sensor at site $08 \mathrm{~b}$ failed. At least during this short period, no remarkable differences could be found, but this does not imply that this is true for the whole summer season. Wind speed shows a clear diurnal cycle with maxima during daytime (Fig. 9d). The daily maxima for the debris cone site were generally in the range of $4-7 \mathrm{~m} \mathrm{~s}^{-1}$ (daily mean $\left.1.2 \mathrm{~m} \mathrm{~s}^{-1}\right)$, and for the grassland site in the range $7-10 \mathrm{~m} \mathrm{~s}^{-1}$ (daily mean $2.9 \mathrm{~ms}^{-1}$ ), a rather noteworthy difference between the two sites that were only $30 \mathrm{~m}$ apart. This difference suggests that the rough surface of the debris cone drag the wind more than the relatively smoother grassland.

\subsection{Highest altitude grasslands $(\approx 2500$ m a.s.I., sites 04 and 09)}

The diurnal cycle at site 04 shows amplitudes between $2-$ $24^{\circ} \mathrm{C}$ with a median value of $17^{\circ} \mathrm{C}$ (Fig. 9a). The time series show almost the identical temperature regimes during nighttime (in most cases the differences were $<0.5^{\circ} \mathrm{C}$ ), only the maxima during daytime are typically $5^{\circ} \mathrm{C}$ higher at site 04 (Fig. 10a). Minimum temperatures are in the range -4 to $10^{\circ} \mathrm{C}$ at both sites, the maxima are in the range $3-32^{\circ} \mathrm{C}$ at site 04 and $3-25^{\circ} \mathrm{C}$ at site 09 .

VPD was only available for site 09 . The highest VPD (9 hPa) was observed at noon. This site shows the lowest daytime VPD compared to the other sites. During the night, a minimum of $2 \mathrm{hPa}$ was measured (Fig. 9b).

The daily maximal radiation was around $130 \mathrm{~W} \mathrm{~m}^{-2}$ higher at site 04 , but it is worth to note that these two sites at the highest elevation did not record the highest radiation levels of all sites (Fig. 10c). As for all other sites, wind speed shows a diurnal cycle with maxima during daytime, of $6-14 \mathrm{~m} \mathrm{~s}^{-1}$ (daily mean $2.0 \mathrm{~m} \mathrm{~s}^{-1}$ ) at site 04 and $6-10 \mathrm{~m} \mathrm{~s}^{-1}$ (daily mean $2.1 \mathrm{~m} \mathrm{~s}^{-1}$ ) at site 09 , which shows that the higher elevated sites are more influenced by the valley wind system during daytime with up-valley winds than by the catabatic downvalley winds which dominate at night. On most days, there were also periods with no wind at both sites. Average hourly wind speeds were thus $1-3.25 \mathrm{~m} \mathrm{~s}^{-1}$, and $1-2.75 \mathrm{~m} \mathrm{~s}^{-1}$ for the site 04 and 09, respectively (Fig. 9d).

\subsection{Topoclimatic variations over Alp Weissenstein - a synthesis}

Piecing all available information from all paired near-surface measurement sites together allows us to characterize the general topoclimatic variations found over the geographic domain of Alp Weissenstein. This information is typically needed for experimental ecosystem studies and is not easily deducible from existing networks for measurements of climatic variables.

The mean diurnal cycles of all measured variables show smaller differences during nighttime than during daytime (Fig. 9). In the case of air temperature, two main factors can be found, (1) an altitudinal gradient and (2) the influence of the vegetation. The range is given by site $02 \mathrm{~b}$ (low altitude, forest) with the highest and site 04 (high altitude, ridge) with the lowest minima. During daytime the differences are much larger, and no clear altitudinal profiles can be found anymore. The highest temperature maximum is found at site $07 \mathrm{~b}$, which is located at the bottom of a debris cone. The altitudinal temperature gradient is clearest for the mean (nighttime) minima (Fig. 11) and could be used for spatial interpolation of temperatures as suggested by Carrega (1995). During daytime, the surface cover becomes more important and thus there is no clear altitudinal gradient of the mean daily maxima (Fig. 11). The topographic map (Fig. 3) 
a)

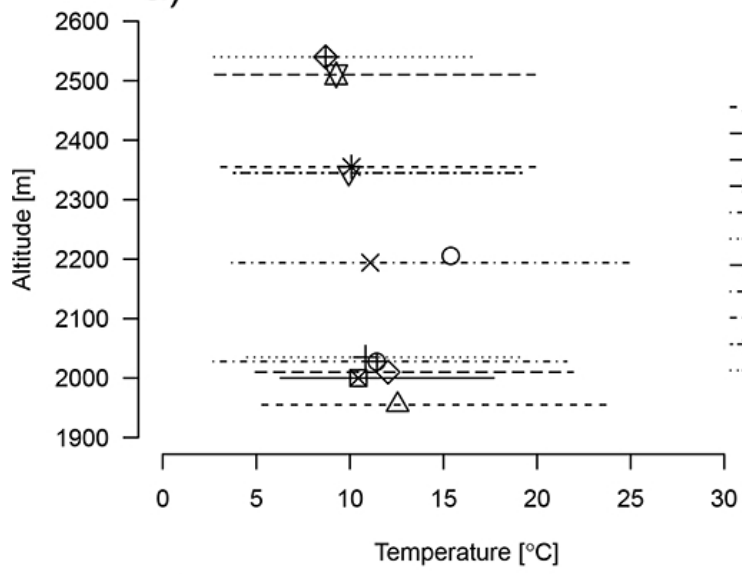

c)

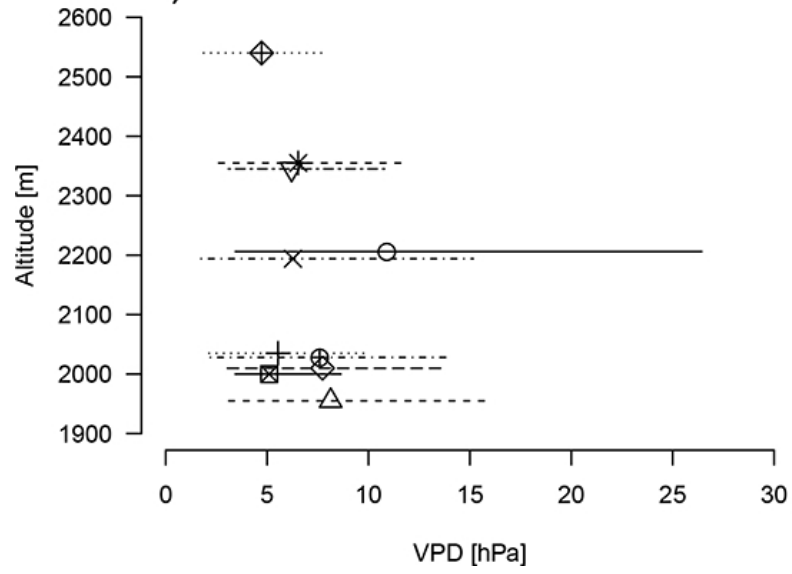

b)

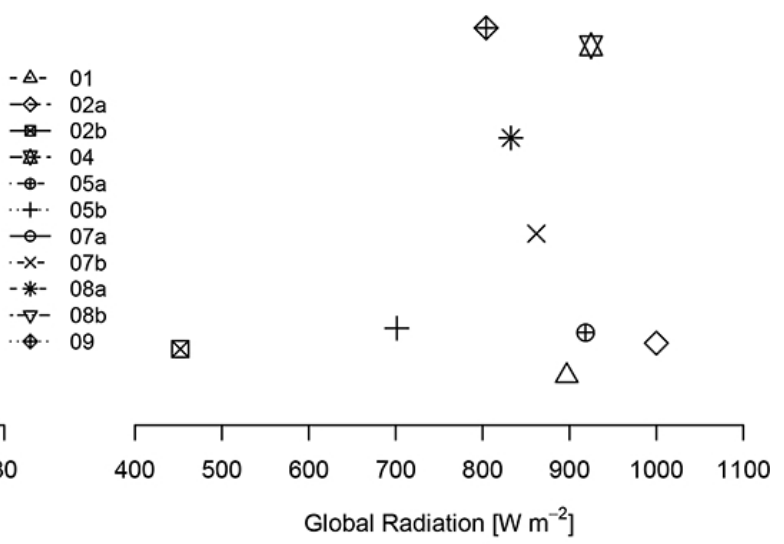

d)

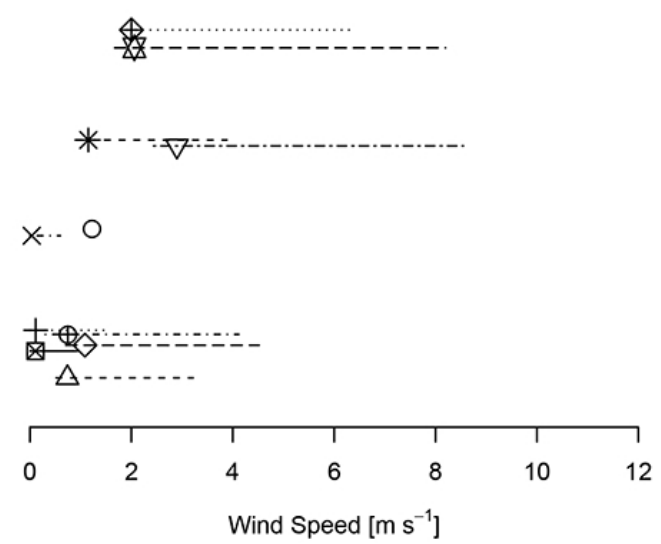

Figure 10. Mean diel minima and maxima (horizontal lines) and means (symbols) of the near-surface measurement sites for (a) air temperature, (b) global radiation (maxima only), (c) water vapor pressure deficit (VPD), and (d) wind speed for the period 25 June 2005, 01:00 CET to 8 July 2005 , 00:30 CET.

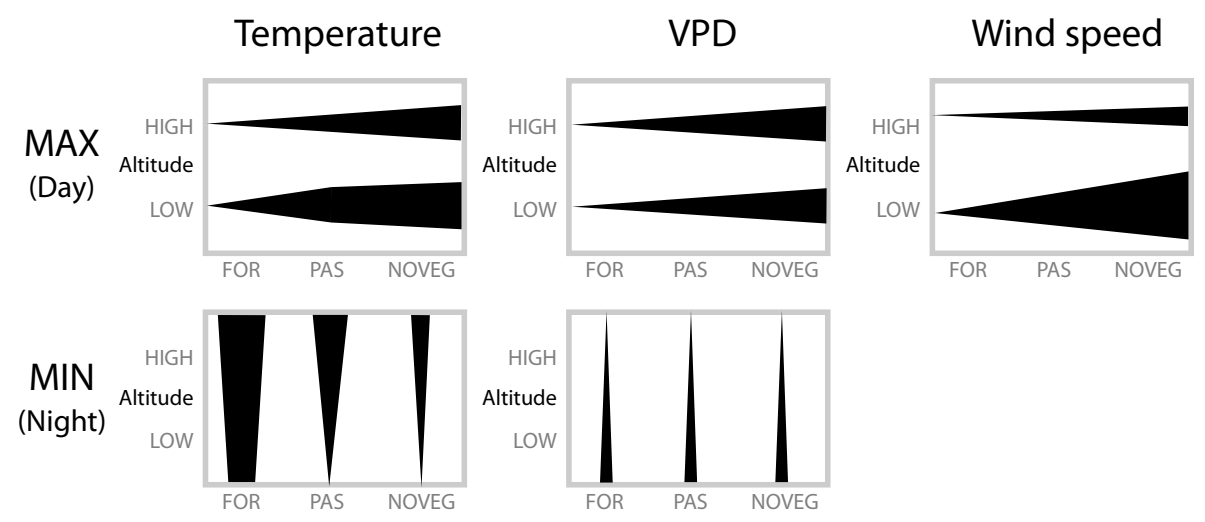

Figure 11. Overall intercomparison of the minima and maxima of air temperature, VPD, and wind speed with respect to surface coverage (horizontal axis) and altitude (vertical axis) for the near-surface measurement sites (FOR = forest, PAS $=$ pasture, NOVEG $=$ no vegetation). The broader the black area, the larger is the difference. 
shows a clear constriction of the valley near the Crap Alv houses. This explains why sites 01, 02a and 02b are not affected by the nocturnal cold-air pooling on the valley floor where sites $05 \mathrm{a}, 05 \mathrm{~b}$ and 06 were located. Although these sites clearly get lower temperatures than the slope sites, they observed warmer nighttime temperatures than on the high altitude ridge of Igl Compass.

VPD is smaller during nighttime at the sites at higher altitudes than at the lower elevated sites. Differences are up to 2$3 \mathrm{hPa}$ and thus rather small. During daytime, the differences increase to $>10 \mathrm{hPa}$. Sites in forests $(02 \mathrm{~b}, 05 \mathrm{~b})$ and the high elevated site 09 show the lowest maximum VPD. The spread between mean daily minima and mean daily maxima is larger for sites with less vegetation cover (Fig. 11). Generally, the diurnal cycles of VPD are very similar to the diurnal cycles in temperature (Fig. 9), suggesting that evaporation and plant transpiration is well below potential evapotranspiration rates under current climate, which means that there is no drought stress for plants.

The higher elevated and more exposed sites also show the highest wind speeds, whereas lowest wind speeds are found at the forest sites (Figs. 9 and 10, sites $02 \mathrm{~b}$ and $05 \mathrm{~b}$ versus sites 02a and 05a). The most pronounced diurnal cycle was found at site $08 \mathrm{~b}$ (alpine grassland next to debris cone) with its maximum hourly mean value over $5.5 \mathrm{~m} \mathrm{~s}^{-1}$ and its minimum hourly mean below $1.25 \mathrm{~m} \mathrm{~s}^{-1}$, whereas the other sites show a range between calm conditions and $3.25 \mathrm{~m} \mathrm{~s}^{-1}$. As expected from the theory of the valley wind system (e.g., Whiteman 2000), the wind speed maxima are found during the high insolation in the late afternoon at all sites. Both, mean daily median wind speed and mean daily maximum wind speed reveal an increase with higher altitude, this gradient is however less pronounced for the maximum values. When comparing the higher elevated station pairs ( 09 versus 04 , and 08 a versus $08 \mathrm{~b}$ ) it becomes apparent that the topography surrounding each station is also an important factor (Fig. 10).

In summary, the topoclimatic variations over Alp Weissenstein are strongly influenced by the valley topography and thus the altitudinal differences, which in turn determine nocturnal conditions and - indirectly via the convective processes within the valley wind system - the daytime maximum wind speed. During the day, topoclimatic differences are primarily related to vegetation cover, a variable which reduces the elevational effect in air temperatures. However, especially the contrast between vegetation-less debris cone and adjacent grassland was much smaller than expected. Wind speeds tended to be smallest and least variable at mid-slope elevations, whereas strongest winds were found, as expected, at upper elevations and more exposed localities. Slope angle and exposition did not strongly influence the measurements presented here since our stations only covered the agriculturally used part of the valley that has a rather similar general slope aspect (S to SW). Hence differential thermal heating is minimized within our domain, but which is certainly a rele- vant additional factor in the hydrological catchment of Alp Weissenstein. Future studies however should aim at longer measurement periods in order to confirm the key findings presented here. Although relative comparisons during short periods should already provide most of the relevant information, it remains a challenge to address climate questions (which typically means: 10 or more years of measurements) with short-term studies.

\section{Conclusions}

We presented the first topoclimatic assessment of the Alp Weissenstein area, located in the upper Albula Valley, based on on-site measurements from one summer season in combination with agrometeorological weather records from June 2005 to December 2008. The overall findings suggest that knowledge gained during an earlier study in the Dischma Valley, around $20 \mathrm{~km} \mathrm{NNE}$ of our study site (Urfer, 1981), is useful for the understanding of local meteorological and climatological conditions at the Alp Weissenstein research station. The topography of the upper Albula Valley where Alp Weissenstein is located, only allows for a shallow temperature inversion during nighttime, which suggests that there is good drainage of cold air to lower elevations and thus a close and direct coupling of climatic conditions on Alp Weissenstein with the regional-scale climate. We could also show that the published altitudinal precipitation gradients (e.g., Ekhardt, 1948; Baumgartner et al., 1983; Schüepp et al., 1978) are of the same order of magnitude as we found for the summer months. From this we conclude that it should be possible to translate regional-scale climate change scenarios (e.g., OcCC 2007) to the local conditions that are relevant for scientific field experiments at Alp Weissenstein.

Acknowledgements. We thank our technician Jürg Schenk, and all 28 students who helped with the field work during the field course in topoclimatology of the University of Bern. Hans Leuenberger, responsible of the Alp Weissenstein ETH research station, made this study possible by providing the necessary support. The availability of meteorological data from the MeteoSwiss digital database is highly appreciated.

Edited by: E. Reynard

Reviewed by: two anonymous referees

\section{References}

Baumgartner, A., Reichel, E., and Weber, G.: Der Wasserhaushalt der Alpen: Niederschlag, Verdunstung, Abfluss und Gletscherspende im Gesamtgebiet der Alpen im Jahresdurchschnitt für die Normalperiode 1931-1960, R. Oldenbourg Verlag, München, Wien, 1983.

Caflisch, C.: Weissenstein am Albula/Crap alv, Bündner Monatsblatt - Zeitschrift für bündnerische Geschichte, Landes- und Volskunde, 2, 65-111, 1954. 
Carrega, P.: A method for the reconstruction of mountain air temperatures with automatic cartographic applications, Theor. Appl. Climatol., 52, 69-84, doi:10.1007/BF00865508, 1995.

Douguedroit, A.: Comparaison entre modèles d'étagement de la végétation et de gradient thermique topoclimatique, Bull. Soc. Bot. Fr.-Actual. Bot., 131, 181-190, 1984.

Ekhardt: Die Niederschlagsverteilung in den Alpen nach dem Anomalienprinzip, Geogr. Ann., 30, 728-739, 1948.

Eugster, W. and Leuenberger, H.: Alpine Landwirtschaft: 40 Jahre ETH-Forschung am Albulapass, Die Alpen, 83, 56-59, 2007.

Eugster, W. and Zeeman, M. J.: Micrometeorological techniques to measure ecosystem-scale greenhouse gas fluxes for model validation and improvement, Int. Congr. Ser., 1293, 66-75, 2006.

Fischer, E.: Globalstrahlungsmessung mit Solarzellen, Seminar thesis, Geographisches Institut, Universität Bern, 2005.

Haeberli, W.: Die Basistemperatur der winterlichen Schneedecke als möglicher Indikator für die Verbreitung von Permafrost in den Alpen, Zeitschrift für Gletscherkunde und Glazialgeologie, XII/2, 221-227, 1973.

Harrison, S. and Kelly, I.: A field-based index of topographic shelter and its application to topoclimatic variation, Appl. Geogr., 16, 53-63, doi:10.1016/0143-6228(95)00025-9, 1996.

Hiller, R.: Growing season $\mathrm{CO}_{2}$ budget of an Alpine grassland in the Swiss Alps, Master's thesis, University of Bern, Institute of Geography, 90 pp., 2007.

Hiller, R., Zeeman, M. J., and Eugster, W.: Eddy covariance flux measurements in the complex terrain of an Alpine valley in Switzerland, Bound.-Lay. Meteorol., 127, 449-467, 2008.

Körner, C.: Winter crop growth at low temperature may hold the answer for alpine treeline formation, Plant Ecology and Diversity, 1, 3-11, doi:10.1080/17550870802273411, 2008.

MeteoSchweiz: Witterungsberichte Juni-Dezember 2005, Zürich, MeteoSchweiz, 2005.

OcCC: Klimaänderung und die Schweiz 2050: Erwartete Auswirkungen auf Umwelt, Gesellschaft und Wirtschaft, ProClim, Bern, 2007.

Schüepp, M., Bouët, M., Bider, M., and Urfer, C.: Regionale Klimabeschreibungen, 1. Teil. Beiheft zu den Annalen der Schweizerischen Meteorologischen Anstalt Nr. 18, SMA, Zürich, 244 pp., 1978.

Sevruk, B.: Systematischer Niederschlagsmessfehler in der Schweiz, in: Der Niederschlag in der Schweiz. Beiträge zur Geologie der Schweiz - Hydrologie Nr. 31, edited by: Sevruk, B., 65-75, 1985.
SMA: Klimaatlas der Schweiz, Zweite Lieferung: Tafel 10.1 - Mittlere jährliche Niederschlagsmengen, Bundesamt für Landestopographie, Bern, 1984.

Urfer, C.: Mittlere Temperatur- und Windverteilung im Dischmatal bei Davos bei typischen sommerlichen Witterungslagen, Tech. Rep. 43, MeteoSchweiz, Zürich, 1981.

Urfer, C., Gensler, G., Ambrosetti, F., and Zenone, E.: Regionale Klimabeschreibungen - 2. Teil: Alpennordhang, Graubünden und Alpensüdseite, Tech. rep., MeteoSchweiz, Zürich, 1979.

Urfer-Henneberger, C.: Neuere Beobachtungen über die Entwicklung des Schönwetterwindsystems in einem v-förmigen Alpental (Dischmatal bei Davos), Arch. Meteorol. Geophys. Bioklimatol., 18, 21-42, 1970.

Urfer-Henneberger, C. and Turner, H.: Bodennahes Windsystem und Temperaturgradienten bei verschiedenen Wetterlagen in einem von Süden nach Norden führenden v-förmigen Alpental, Arch. Meteorol. Geophys. Bioklimatol., B31, 253-271, 1982.

Vonlanthen, C. M., Kammer, P. M., Eugster, W., Bühler, A., and Veit, H.: Alpine vascular plant species richness: the importance of daily maximum temperature and $\mathrm{pH}$, Plant Ecol., 184, 13-25, 2006a.

Vonlanthen, C. M., Bühler, A., Veit, H., Kammer, P. M., and Eugster, W.: Alpine plant communities: a statistical assessment of their relation to microclimatological, pedological, geomorphological, and other factors, Phys. Geogr., 27, 137-154, $2006 \mathrm{~b}$.

Weiss, R.: Das Alpwesen Graubündens: Wirtschaft, Sachkultur, Recht, Älplerarbeit und Älplerleben, Eugen Rentsch Verlag, Erlenbach-Zürich, 385 pp., 1941.

Whiteman, C. D.: Breakup of Temperature Inversions in Deep Mountain Valleys: Part I. Observations, J. Appl. Meteorol., 21, 270-289, 1982.

Whiteman, C. D.: Mountain Meteorology, Oxford University Press, New York, Oxford, 2000.

Zeeman, M. J., Hiller, R., Gilgen, A. K., Michna, P., Plüss, P., Buchmann, N., and Eugster, W.: Management and climate impacts on net $\mathrm{CO}_{2}$ fluxes and carbon budgets of three grasslands along an elevational gradient in Switzerland, Agr. Forest Meteorol., 150, 519-530, doi:10.1016/j.agrformet.2010.01.011, 2010.

Zhenlin, Y., Hanna, E., and Callaghan, T. V.: Modelling surface-air-temperature variation over complex terrain around Abisko, Swedish lapland: uncertainties of measurements and models at different scales, Geogr. Ann. A, 93A, 89-112, doi:10.1111/j.1468-0459.2011.00005.x, 2011. 